\title{
Supplementary irrigation in Sudan grass: Leaf area index, dry matter production and water use efficiency
}

\section{Irrigação suplementar em capim Sudão: Índice de área foliar, produção de massa seca e eficiência de utilização da água}

\author{
Wellington MEZZOMO'; Marcia Xavier PEITER ${ }^{2}$; Adroaldo Dias ROBAINA ${ }^{3}$; Jardel Henrique KIRCHNER ${ }^{5}$; \\ Rogério Ricalde TORRES ${ }^{5}$; Bruna Dalcin PIMENTA4; Anderson Crestani PEREIRA ${ }^{6}$; \\ Luís Humberto Bahú BEN ${ }^{4}$; Marcos Vinicius LOREGIAN ${ }^{7}$; Pablo Eanes $\mathrm{COCCO}^{4}$ \\ ${ }^{1}$ Autor para correspondência Doutorando na Universidade Federal de Santa Maria, Departamento de Engenharia Rural, \\ Programa de Pós Graduação em Engenharia Agrícola, Área de concentração: Engenharia de Água e Solo, Laboratório de \\ Engenharia de Irrigação, Av. Roraima, n¹000, Bairro Camobi, Santa Maria - RS, wmezzomo@hotmail.com \\ ${ }^{2}$ Professora Doutora Associada ao Departamento de Engenharia Rural da Universidade Federal de Santa Maria, \\ mpeiter@gmail.com \\ ${ }^{3}$ Professor Doutor Titular no Departamento de Engenharia Rural da Universidade Federal de Santa Maria, \\ diasrobaina@gmail.com \\ ${ }^{4}$ Doutorando no Programa de Pós Graduação em Engenharia Agrícola, Universidade Federal de Santa Maria, \\ brunadpimenta@gmail.com, luishumbertoben@gmail.com, cocco.pablo@hotmail.com \\ ${ }^{5}$ Professor Doutor do Instituto Federal de Educação, Ciências e Tecnologia do Rio Grande do Sul, rogeriocprtorres@gmail.com, \\ jardelkirchner@hotmail.com \\ ${ }^{6}$ Mestrando no Programa de Pós Graduação em Engenharia Agrícola, Universidade Federal de Santa Maria, \\ acrestanipereira@gmail.com \\ ${ }^{7}$ Mestrando no Programa de Pós Graduação em Agronomia, Universidade Federal de Santa Maria, \\ vinicius.loregian@hotmail.com
}

Recebido em: 01-04-2019; Aceito em: 13-09-2019

\begin{abstract}
The study was carried out in the municipality of Santiago, Rio Grande do Sul, Brazil, with the objective of evaluating the effect of the application of increasing supplementary irrigation depths on the leaf area index, dry matter accumulation and water use efficiency of Sudan grass (Sorghum sudanense (Piper) Stapf) submitted to four standardization cuts of the aerial part, at 50,80,110 and 140 days after sowing (DAS) with irrigation depths of $60 \%$, $80 \%, 100 \%, 120 \%$ and $140 \%$ of the difference between reference evapotranspiration (ETo) and effective precipitation-(EP), plus the control treatment (without irrigation: only EP). Between cuts, leaf area index and shoot dry mass were evaluated every fortnightly. The experimental design was in randomized blocks, with six treatments and four blocks, totaling 24 experimental units. Both the leaf area index and the dry mass production showed an increasing behavior until the treatment with $100 \%$ of ETo-EP; after this treatment the production was stable, with some of the highest averages in the treatment with 140\% ETo-EP, and the lowest averages were observed in the treatment without irrigation. There was a decrease in dry mass production throughout the experiment due to the natural loss of the yield potential of the crop. At second cut (80 DAS), the leaf area index showed the highest values. The highest water use efficiency in the sum of the four cuts was in the treatment with $100 \%$ of ETo-EP and the lowest in the treatment with $60 \%$ of ETo-EP.
\end{abstract}

Additional keywords: standardization cuts; evapotranspiration; Sorghum sudanense (Piper) Stapf.

\section{Resumo}

O estudo foi realizado no município de Santiago, Rio Grande do Sul, Brasil, com o objetivo de avaliar o efeito da aplicação de lâminas crescentes de irrigação suplementar no índice de área foliar, acúmulo de massa seca e eficiência de utilização da água do capim Sudão (Sorghum sudanense (Piper) Stapf) submetido a quatro cortes de uniformização da parte aérea, aos 50, 80, 110 e 140 dias após a semeadura (DAS), com profundidades de irrigação de $60 \%, 80 \%, 100 \%, 120 \%$ e $140 \%$ da diferença entre a evapotranspiração de referência (ETo) e a precipitação efetiva (EP), mais o tratamento testemunha (sem irrigação: somente EP). Entre os cortes, o índice de área foliar e a massa seca da parte aérea foram avaliados quinzenalmente. O delineamento experimental foi em blocos casualizados, com seis tratamentos e quatro blocos, totalizando 24 unidades experimentais. Tanto o índice de área foliar como a produção de massa seca apresentaram comportamento crescente até o tratamento com $100 \%$ da ETo-EP, após esse tratamento a produção apresentou-se estável, com algumas das maiores médias no tratamento com $140 \%$ da ETo-EP, e as menores médias foram observadas no tratamento sem irrigação. Houve uma diminuição na produção de massa seca ao longo do experimento devido à perda natural do potencial de rendimento da cultura. No momento do segundo corte (80 DAS), o índice de área foliar apresentou os maiores valores. A maior eficiência de utilização da água no somatório dos quatro cortes foi no tratamento com $100 \%$ da ETo-EP e a menor no tratamento com $60 \%$ da ETo-EP.

Palavras-chave adicionais: Cortes de uniformização, evapotranspiração, Sorghum sudanense (Piper) Stapf. 


\section{Introduction}

In Rio Grande do Sul state, the region of Santiago stands out as a traditional beef-producing region. However, there are periods of drought that in some cases compromise the production of agricultural crops (Gomes et al., 2014), directly affecting the gain of animal weight, thus irrigation is an important tool to maintain the viability of the activity.

Oliveira et al., (2016) studying the potential of irrigated forage production, affirm that the use of irrigation for forage production, especially in dry seasons of the year, allows a significant increase in herd productivity levels, due to greater forage availability and quality.

It should be highlighted that irrigation is an important technique to increase the dry mass production and to improve the quality of the forage produced by increasing the leaf area index (Bartero et al., 2013), being a viable alternative for the increase of agricultural productivity, adequately supplying the demand for water by the crop, especially in times of irregular rainfall (Lopes et al., 2011).

In order to perform irrigation management efficiently, it is indispensable to know the behavior of the crop in relation to water availability, in order to maintain irrigation levels within crop requirement (Gomes et al., 2015), it is essential to know the water use efficiency (WUE), which must be determined by the quantification of production and total water applied throughout the crop cycle (Monteiro et al., 2008).

Another fundamental aspect, besides water availability, it is the use of good quality seeds for the proper establishment of the crop. Due to the need for certified seeds of Sudan grass (Sorghum sudanense (Piper) Stapf), in 2013 the cultivar BRS ESTRIBO was launched. Although the use of the cultivar is recent in the southern region of Brazil, farmers approved the advantages of this Sudan grass in relation to other summer grasses used in the region (Embrapa, 2014).

The crop stands out for high nutritional quality, great forage production, early sowing possibility, long production cycle, rusticity in terms of water stress and soil nutritional conditions, is well suited to dry and hot climates, it has a capacity for recovery after cutting or grazing superior to the great majority of the annual grasses used (Bibi et al., 2010; Embrapa, 2015).

Owing to the fact that it is a crop with high forage potential and the research diverges on information on the leaf area index and dry mass production when supplemented irrigation, it is justified to carry out the present work, which aims to analyze the leaf area index, dry mass production and water use efficiency (WUE) of Sudan grass subjected to different supplementary irrigation depths in four standardization cuts of plant shoots.

\section{Materials and methods}

\section{Location and climatic characterization}

The experimental study was carried out in the $2014 / 2015$ harvest in the municipality of Santiago, RS, where the geographical coordinates are approximately, $29^{\circ} 09^{\prime} 50^{\prime \prime} \mathrm{S}, 54^{\circ} 51^{\prime} 32^{\prime \prime} \mathrm{O}$ and $439 \mathrm{~m}$ of altitude.

The average rainfall at the study site over the last 10 years is $1769 \mathrm{~mm}$, but the distribution of rainfall throughout the year is irregular, especially in the summer, with periods of water deficit to the plants, as evapotranspiration at this time of the year is high and rainfall does not normally supply the water demand of plants. Its predominant climate, according to the scale of Köppen (Moreno, 1961), is characterized as humid subtropical (Cfa).

During the experiment, there was a great variation of the minimum, maximum and average daily temperatures. The average temperature from November to April in the $2014 / 2015$ harvest was $22.7^{\circ} \mathrm{C}$, average of the minimum was $17.5^{\circ} \mathrm{C}$ and maximum $27.8^{\circ} \mathrm{C}$, with an average relative humidity of $82.3 \%$.

The total rainfall during the entire experimental period (140 days) was $883 \mathrm{~mm}$. However, according to the methodology adopted, developed by Millar (1978), which takes into account soil type, slope and cultivation condition; the fraction of precipitation lost by water flows, which consequently became unavailable to the plants, was $30 \%$ of the total rainfall.

Therefore, the volume of water infiltrated and available to the plants was $618 \mathrm{~mm}$, which is called effective precipitation. Although the precipitated water volume was above the average, the distribution of rainfall during the period was irregular, causing periods of drought, making the use of supplementary irrigation necessary. The representation of the effective precipitation (EP), reference evapotranspiration (ETo) and the supplementary irrigation depth applied in the treatment with $100 \%$ of ETo-EP during the experimental period is shown in Figure 1, at weekly intervals due to the irrigation shift.

Seven irrigations were required, three of them in consecutive weeks in the interval between sowing and the first cut. In the period of the second cut one irrigation was performed, as well as in the third cut and two irrigations in the fourth cut being in two consecutive weeks.

In previous studies in this same location and period, water deficit episodes were also observed, directly influencing leaf area index and dry mass production of maize, soybean and bean crops, and in those cases the use of irrigation also showed an increase in the analyzed variables, presenting proportional responses to the irrigation levels tested (Parizi et al., 2009; Gomes et al., 2014).

\section{Soil characterization}

At the site of the experiment, the soil is classified as typical Dystrophic Red Latosol (Streck et al., 2008). The characteristics of this soil are favorable for agricultural production, since they are soils with high porosity, friable, well-structured and deep, which confers adequate conditions for root development.

The particle density was determined by the volumetric flask method proposed by Gubiani et al. (2006), while the other variables were determined by the methodology proposed by Embrapa (1997). The soil physical characterization of the experimental area is represented in Tables 1 and 2 , respectively. 


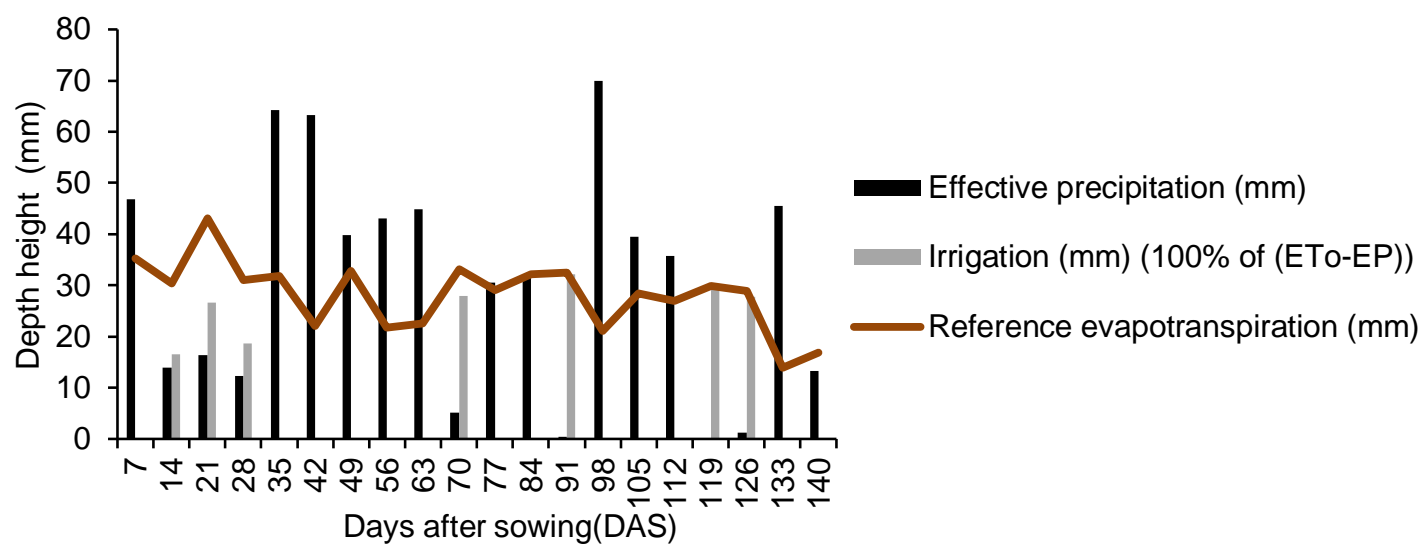

Figure 1- Consumption and water supply accumulated weekly throughout the crop cycle.

Table 1 - Soil size distribution and textural class, at different depths (averages of three replications).

\begin{tabular}{ccccl}
\hline \multirow{2}{*}{$\begin{array}{c}\text { Soil depths } \\
(\mathrm{cm})\end{array}$} & Sand & \multicolumn{1}{c}{ Silt } & Clay & Textural class \\
\cline { 2 - 4 } & $-\cdots$ & 18.48 & 26.24 & \\
\hline $0-20$ & 55.28 & Sandy clayloam \\
$20-40$ & 48.97 & 17.09 & 33.95 & Sandy clayloam \\
$40-60$ & 43.54 & 15.46 & 41.01 & Clay \\
$60-80$ & 42.59 & 15.42 & 41.99 & Clay \\
$80-100$ & 40.81 & 15.19 & 44.00 & Clay \\
\hline
\end{tabular}

In table 2 are represented the values of soil bulk density, particle density, macroporosity, microporosity

and total porosity in the different layers of the soil analyzed.

Table 2 - Soil density (Sd), particle density (Pd) and porosity (macro, micro and total), in different depths (average of three repetitions).

\begin{tabular}{cccccc}
\hline \multirow{2}{*}{$\begin{array}{c}\text { Soil depths } \\
(\mathrm{cm})\end{array}$} & \multicolumn{2}{c}{$\begin{array}{c}\text { Density } \\
\left(\mathrm{g} \mathrm{cm}^{-3}\right)\end{array}$} & \multicolumn{3}{c}{ Porosity } \\
\cline { 2 - 5 } & $\mathrm{Sd}$ & $\mathrm{Pd}$ & Macroporosity & Microporosity & Total porosity \\
\hline $0-20$ & 1.65 & 2.65 & 12.94 & 24.98 & 37.92 \\
$20-40$ & 1.44 & 2.65 & 15.33 & 30.47 & 45.80 \\
$40-60$ & 1.27 & 2.65 & 22.47 & 29.76 & 52.22 \\
$60-80$ & 1.20 & 2.65 & 21.29 & 33.45 & 54.74 \\
$80-100$ & 1.25 & 2.65 & 20.22 & 32.45 & 52.66 \\
\hline
\end{tabular}

Sowing and basal fertilization were carried out jointly by means of a seeder-fertilizer, being the sowing density of 25 seeds per linear meter with spacing between rows of $0.36 \mathrm{~m}$, the average population density after emergence was 23.4 plants per linear meter.

According to the interpretation of the chemical analysis of the soil presented in Table 3 and following the indications of the Manual of Fertilization and Liming for the States of Rio Grande do Sul and Santa Catarina (CQFS RS / SC, 2016), the basal fertilization was carried out in the sowing line, with $250 \mathrm{~kg} \mathrm{ha}^{-1}$ of the fertilizer applied with the commercial formula 5-20-20.
Nitrogen fertilization was done in a fractional way, with the first application in the cover at the beginning of the tillering, at 25 days after sowing (DAS) and after each cut of uniformity at 50, 80 and 110 DAS. To determine the amount of $\mathrm{N}$ to be applied in the cover, the organic matter content presented in the chemical report of the soil was evaluated, applying $150 \mathrm{~kg} \mathrm{ha}^{-1}$ of urea at the beginning of the tillering and after each cut of uniformity performed homogeneously in all treatments, totaling $600 \mathrm{~kg} \mathrm{ha}^{-1}$ of urea in cover throughout the crop cycle. 
Table 3 - Soil chemical characteristics of the experimental area.

\begin{tabular}{|c|c|c|c|c|c|c|c|c|c|c|c|c|}
\hline \multirow{2}{*}{$\begin{array}{c}\text { Depth } \\
(\mathrm{cm})\end{array}$} & $\begin{array}{c}\mathrm{pH} \\
\text { water }\end{array}$ & $\mathrm{Ca}$ & $\mathrm{Mg}$ & Al & $\mathrm{T}$ & \multicolumn{2}{|c|}{ Saturation (\%) } & \multirow{2}{*}{$\begin{array}{l}\text { SMP } \\
\text { index }\end{array}$} & \multirow{3}{*}{$\frac{\mathrm{OM}}{\frac{(\%)}{28}}$} & \multirow{3}{*}{$\begin{array}{c}\text { Clay } \\
(\%) \\
44\end{array}$} & $\begin{array}{c}\mathrm{P} \\
\text { Mehlich }\end{array}$ & \multirow[b]{2}{*}{$\left.n^{-3}\right)$} \\
\hline & $(1: 1)$ & --- & $(\mathrm{cmol}$ & $\left.\mathrm{dm}^{-3}\right)$ & $-\cdots$ & $\mathrm{Al}$ & Base & & & & (mg & \\
\hline $0-10$ & 5.2 & 5.2 & 1.7 & 0.1 & 7.6 & 1.3 & 68.3 & 6.2 & & & 18.9 & 252 \\
\hline
\end{tabular}

\section{Pest and disease management}

The application of agrochemicals (fungicides, herbicides and insecticides) was carried out in a broad and homogeneous way throughout the experimental area, applied preventively, or when the first signs of damage to the plants appeared, or emergence of weeds, aiming to eliminate the interference of these factors in the experimental area.

The control of fungal diseases was carried out in a preventive manner, at $30 \mathrm{DAS}$, when the insults were observed on the plants, the fungicide Tebuconazol (Constant ${ }^{\circledR}$ ) was used in the dosage of $1 \mathrm{~L} \mathrm{ha}^{-1}$ (a.i. $200 \mathrm{~g} \mathrm{~L}^{-1}$ ) in the two applications.

Pest control was carried out through an insecticide, where the main pest was the armyworm. Four applications were performed at 30, 65, 95 and 120 DAS. The insecticide used was Chlorpyrifos (Vexter $\left.{ }^{\circledR}\right)$ at the dosage of $0.6 \mathrm{~L} \mathrm{ha}^{-1}$ (a.i. $480 \mathrm{~g} \mathrm{~L}^{-1}$ ) with $150 \mathrm{~L} \mathrm{ha}^{-1}$ of volume rate.

\section{Irrigation management}

The treatments consisted of five different supplementary irrigation depths, evaluated in four blocks, totaling 24 experimental units, using a randomized block design. The supplementary irrigation depths (SID) used were $60 \%, 80 \%, 100 \%, 120 \%$ and $140 \%$ of the reference evapotranspiration minus effective precipitation (ETo -EP) when ETo>EP, plus the control treatment (without irrigation: EP only).

An automatic meteorological station, model Vantage Pro, was used, located approximately 200 meters from the experimental area and programmed to send data in 15 minute intervals to the central, monitoring the following variables daily: rainfall $(\mathrm{mm})$, temperature $\left({ }^{\circ} \mathrm{C}\right)$, relative humidity $(\%)$, solar radiation $\left(\mathrm{w} \mathrm{m} \mathrm{m}^{-2}\right)$, photoperiod (hours) and wind speed $\left(\mathrm{m} \mathrm{s}^{-1}\right)$, information needed to determine the reference evapotranspiration (ETo) using the Penman-Monteith / FAO method (ALLEN, et al., 2006).

Irrigation management was established with a seven-days fixed irrigation shift, due to the soil's water storage capacity to $50 \mathrm{~cm}$ deep being $53.3 \mathrm{~mm}$ and the maximum reference evapotranspiration of $6.5 \mathrm{~mm}$ day $^{-1}$ according to historical data for the last 5 years. In this study, the maximum reference evapotranspiration was $6.16 \mathrm{~mm}$ day $^{-1}$ in the accumulated of the third week of cultivation. Thus, supplementary irrigations were carried out weekly, whenever the effective precipitations of the period did not fully supply the reference evapotranspiration.
A conventional sprinkler irrigation system was used, consisting of a main line measuring 60 meters and six fixed lateral lines measuring 48 meters, covering the four blocks used. The spacing of the lateral lines was 12 $\mathrm{m}$, as well as the spacing between sprinklers, which are connected to an elevation with a height of $1.5 \mathrm{~m}$ in relation to the ground.

The sprinklers used were from the brand NAANDAINJAIN, model $4271 / 2$ ", complete rotation, with different nozzles in interspersed lines, which are: $4.0 \mathrm{~mm} \times 3.5 \mathrm{~mm} ; 3.2 \mathrm{~mm} \times 3.0 \mathrm{~mm}$ and $2.8 \mathrm{~mm} \times 2.4$ $\mathrm{mm}$ with the objective of forming five different irrigation depths, by overlapping lines with different rates of application, subsequently the Christiansen uniformity test was performed for the calibration and adjustment of the irrigation depths, using drawer registers installed at the beginning of each lateral line in order to assist in the adjustment of the tested irrigation depths, in order to avoid interference between treatments, $1.45 \mathrm{~m}$ borders were left in each plot.

\section{Sampling and quantification}

Four standardization cuts were performed, at 50 , 80,110 and 140 days after sowing (DAS). For the evaluation of leaf area index (LAl) and the production of dry mass (DM) seven evaluations at biweekly intervals were performed after the first cut (50 DAS), being them at $50,65,80,94,110,124$ and 140 DAS, according to the methodology used by Kirchner et al.(2017), Torres et al. (2019) and Mezzomo et al. (2020).

Each experimental plot was constituted between two lateral lines, between two sprinklers of each line, having nozzles with different diameters, being composed by 33 sowing lines and spacing of $0.36 \mathrm{~m}$, with 12 meters in length each line, with 25 plants per linear meter, it was considered a border with $1.45 \mathrm{~m}$ and 25 useful lines for the collection of samples.

Three samples at linear $0.5 \mathrm{~m}$ per parcel were collected for both variables. For the LAI, the cut was done close to the soil, in order to account for all the leaves presents in the plants. For DM, the cut was performed at $15 \mathrm{~cm}$ of height in relation to the soil, being the cutting height indicated by Silveira et al. (2015) for the adequate regrowth of the crop.

The free software ImageJ (Schneider et al., 2012) was used to quantify the leaf area index of the samples, each leaf being extended on a white background and later photographed. The software, by means of contrast between the white background and the leaves, assigns values to the foliar areas, and later it is possible to calculate the index of existing leaf area, due to the use of a square of known area of $100 \mathrm{~cm}^{2}$. 
The leaf- stem ratio was determined together with the leaf area assessment, starting at 50 DAS and afterwards every fifteen days, by separating the fractions of leaves and stems, and then they are taken to the oven with forced air circulation at $65^{\circ} \mathrm{C}$ until they reach constant mass, in order to quantify the dry mass of the components by means of a precision scale, allowing to obtain the value of the variable, as well as the production of total dry mass (DM) at biweekly intervals after the first standardization cut (50 DAS).

\section{Experimental design and statistical analysis}

The data obtained were statistically evaluated by analysis of variance (ANOVA) with a significance of $5 \%$ error probability and, later, when significant effects were observed, the treatments were submitted to regression analysis. For statistical analysis, the SISVAR 5.3 software was used.

The treatments consisted of six different irrigation depths, evaluated in four blocks, totaling 24 experimental units, the data were analyzed in a randomized block design.

\section{Results and discussion}

Table 4 presents the results of the water balance weekly, with the respective supplementary irrigation depths, as well as the total water applied in each cut and the grand total over the crop cycle (irrigation depth + effective precipitation (EP)), the treatment considered $0 \%$ of ETo received only effective rainwater throughout the cycle.

Dry mass presents itself as a factor dependent on leaf area index (LAI), where the decrease of LAI interferes negatively, directly and proportionately in the production of dry mass (DM) (Oliveira et al., 2007).

Figure $2 \mathrm{~A}$ and Figure $2 \mathrm{~B}$ show the behavior of DM and LAI production at the different irrigation depths tested at the time of the first cut (50 DAS). Both the DM and the LAI presented statistical significance at the level of $5 \%$ of probability of error between the scenarios with and without irrigation, for all periods, being carried out to complement the regression analysis.

Table 4 - Effective precipitation (EP), Reference evapotranspiration (ETo) and supplementary irrigation depths (SID) weekly, totals and means per cut and throughout the crop cycle.

\begin{tabular}{|c|c|c|c|c|c|c|c|c|c|}
\hline \multirow{3}{*}{ Cuts } & \multirow{3}{*}{ (1) DAS } & \multirow{2}{*}{ EP } & \multirow{2}{*}{ ETo } & \multicolumn{6}{|c|}{ SID [\% (ETo - EP)] } \\
\hline & & & & 0 & 60 & 80 & 100 & 120 & 140 \\
\hline & & \multicolumn{8}{|c|}{ 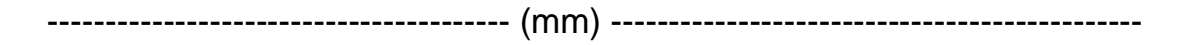 } \\
\hline \multirow{7}{*}{$\begin{array}{c}1^{1 \mathrm{st}} \\
(0-50 \mathrm{DAS})\end{array}$} & 7 & 46.9 & 35.3 & 0 & 0 & 0 & 0 & 0 & 0 \\
\hline & 14 & 13.9 & 30.4 & 0 & 9.9 & 13.2 & 16.5 & 19.8 & 23.1 \\
\hline & 21 & 16.4 & 43.1 & 0 & 16.0 & 21.3 & 26.7 & 32.0 & 37.4 \\
\hline & 28 & 12.3 & 31.0 & 0 & 11.2 & 14.9 & 18.7 & 22.4 & 26.2 \\
\hline & 35 & 64.3 & 31.8 & 0 & 0 & 0 & 0 & 0 & 0 \\
\hline & 42 & 63.3 & 22.1 & 0 & 0 & 0 & 0 & 0 & 0 \\
\hline & 49 & 39.8 & 32.8 & 0 & 0 & 0 & 0 & 0 & 0 \\
\hline \multicolumn{4}{|c|}{ Total Irrigation Depths (SID) } & 0 & 37.1 & 49.4 & 61.9 & 74.2 & 86.7 \\
\hline \multirow{2}{*}{\multicolumn{2}{|c|}{$\begin{array}{l}\text { Total EP+SID } \\
\text { ETo Mean }\left(\mathrm{mm} \mathrm{d}^{-1}\right)\end{array}$}} & 256.9 & 226.5 & 256.9 & 294.0 & 306.3 & 318.8 & 331,1 & 343,6 \\
\hline & & - & 4.6 & - & - & - & - & - & - \\
\hline \multirow{4}{*}{$\begin{array}{c}2^{\text {nd }} \\
(50-80 \text { DAS })\end{array}$} & 56 & 43 & 21.8 & 0 & 0 & 0 & 0 & 0 & 0 \\
\hline & 63 & 44.9 & 22.6 & 0 & 0 & 0 & 0 & 0 & 0 \\
\hline & 70 & 5.2 & 33.1 & 0 & 16.7 & 22.3 & 27.9 & 33.5 & 39.0 \\
\hline & 77 & 30.5 & 29.1 & 0 & 0 & 0 & 0 & 0 & 0 \\
\hline \multicolumn{4}{|c|}{ Total Irrigation Depths (SID) } & 0 & 16.7 & 22.3 & 27.9 & 33.5 & 39.0 \\
\hline Total EP+SID & & 123.6 & 106.5 & 123.6 & 140.3 & 145.9 & 151.5 & 157.1 & 162.6 \\
\hline \multicolumn{2}{|c|}{ ETo Mean $\left(\mathrm{mm} \mathrm{d}^{-1}\right)$} & - & 3.8 & - & - & - & - & - & - \\
\hline \multirow{4}{*}{$\begin{array}{c}3^{\text {rd }} \\
(80-110 \text { DAS })\end{array}$} & 84 & 32.2 & 32.2 & 0 & 0 & 0 & 0 & 0 & 0 \\
\hline & 91 & 0.4 & 32.5 & 0 & 19.2 & 25.7 & 32.1 & 38.5 & 44.9 \\
\hline & 98 & 70.0 & 21.1 & 0 & 0 & 0 & 0 & 0 & 0 \\
\hline & 105 & 39.5 & 28.4 & 0 & 0 & 0 & 0 & 0 & 0 \\
\hline \multicolumn{4}{|c|}{ Total Irrigation Depths (SID) } & 0 & 19.2 & 25.7 & 32.1 & 38.5 & 44.9 \\
\hline \multicolumn{2}{|c|}{ Total EP+SID } & 142.1 & 114.1 & 142.1 & 161.3 & 167.8 & 174.2 & 180.6 & 187.0 \\
\hline \multicolumn{2}{|c|}{ ETo Mean $\left(\mathrm{mm} \mathrm{d}^{-1}\right)$} & - & 4.1 & - & - & - & - & - & - \\
\hline
\end{tabular}


Table 4 - Cont...

\begin{tabular}{|c|c|c|c|c|c|c|c|c|c|}
\hline \multirow{3}{*}{ Cuts } & \multirow{3}{*}{ (1) DAS } & \multirow{2}{*}{ EP } & \multirow{2}{*}{ ETo } & \multicolumn{6}{|c|}{ SID [\% (ETo - EP)] } \\
\hline & & & & 0 & 60 & 80 & 100 & 120 & 140 \\
\hline & & \multicolumn{8}{|c|}{ - } \\
\hline \multirow{5}{*}{$\begin{array}{c}4^{\text {th }} \\
(110-140 \text { DAS })\end{array}$} & 112 & 35.7 & 27.0 & 0 & 0 & 0 & 0 & 0 & 0 \\
\hline & 119 & 0.1 & 29.9 & 0 & 17.9 & 23.8 & 29.8 & 35.8 & 41.7 \\
\hline & 126 & 1.2 & 28.9 & 0 & 16.6 & 22.2 & 27.7 & 33.2 & 38.8 \\
\hline & 133 & 45.5 & 13.9 & 0 & 0 & 0 & 0 & 0 & 0 \\
\hline & 140 & 13.2 & 16.9 & 0 & 0 & 0 & 0 & 0 & 0 \\
\hline \multicolumn{4}{|c|}{ Total Irrigation Depths (SID) } & 0 & 34.5 & 46.0 & 57.5 & 69.0 & 80.5 \\
\hline Total EP+SID & & 95.7 & 116.6 & 95.7 & 130.2 & 141.7 & 153.2 & 164.7 & 176.2 \\
\hline ETo Mean $(\mathrm{mm}$ & & - & 3.3 & - & - & - & - & - & - \\
\hline \multicolumn{4}{|c|}{ Grand Total Irrigation depths (SID) } & 0 & 107.5 & 143.4 & 179.4 & 215.2 & 251.1 \\
\hline Grand Total EP. & SID & 618.3 & 563.7 & 618,3 & 725.8 & 751.7 & 797.7 & 833.5 & 869.4 \\
\hline \multicolumn{3}{|c|}{ ETo General Mean $\left(\mathrm{mm} \mathrm{d}^{-1}\right)$} & 4.0 & - & - & - & - & - & - \\
\hline
\end{tabular}

(1) DAS - days after sowing.

A

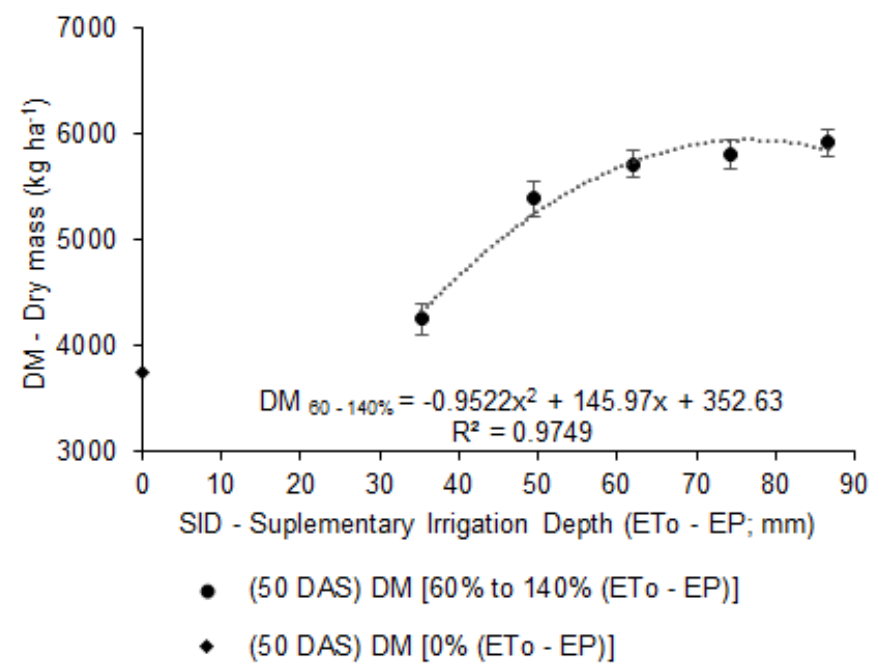

B

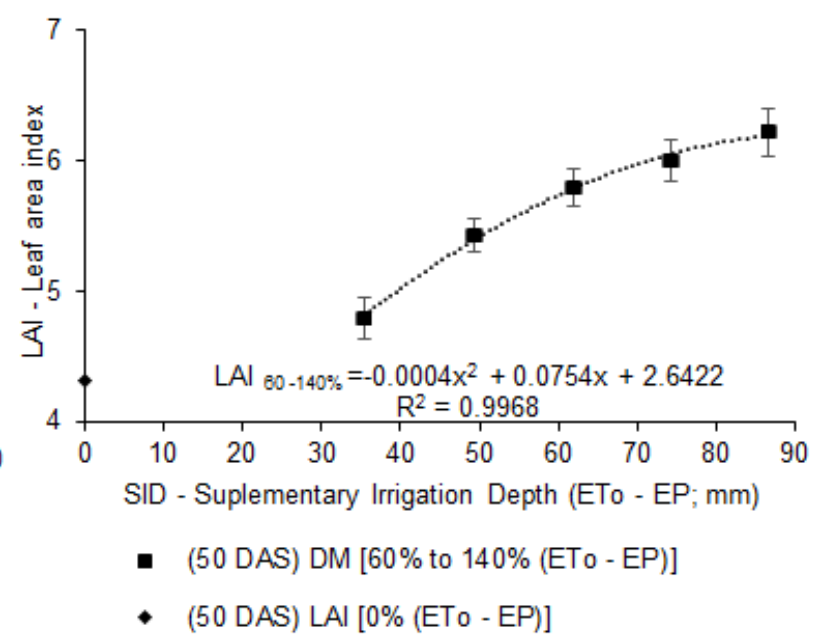

Figure 2 - Dry mass (A) and leaf area index (B) at 50 days after sowing (50 DAS) under irrigation depths $0 \%, 60 \%$, $80 \%, 100 \%, 120 \%$ and $140 \%$ of ETo-EP, with standards errors for each dot represented.

There was a considerable variation in DM and LAI production according to the supplementary irrigation depths tested, presenting in both variables quadratic behaviors, providing greater production increase between the irrigation depths with $60 \%$ and $80 \%$, after these depths there was a smaller increase in both DM and LAl.

According to standard errors, production stabilization between irrigation levels with 100\%, 120\% and $140 \%$ is observed, showing no statistically significant difference between these treatments, probably because the water demand of the crop has been fully met.

LAl presented in the treatment without irrigation the average of 4.32 , while the treatment with the irrigation depth at $140 \%$ of ETo-EP presented 6.21 , representing an increase of $30.5 \%$. Same behavior is observed in the DM graph, where the treatment without irrigation presented a production of $3750.00 \mathrm{~kg} \mathrm{ha}^{-1}$, and the treatment with irrigation depth at $140 \%$ of ETo-EP produced $5918.26 \mathrm{~kg} \mathrm{ha}^{-1}$, presenting a variation of $2168.29 \mathrm{~kg} \mathrm{ha}^{-1}$, corresponding to an increase of $37.7 \%$ of DM.

Ferreira et al. (2000) working with the Sudan grass crop in the municipality of Prudente Morais - MG, with sowing in February, found results of dry mass production that are in agreement with what the observed in the present study. Where, at 56 days after germination, it obtained a dry mass production of $5370 \mathrm{~kg} \mathrm{ha}^{-1}$, this difference of $9.3 \%$ in relation to the production observed in this work at 50 DAS, can be attributed to the climatic conditions of the place, growing season and also to the use of non-certified seeds.

Evaluating different sowing times in the Sudan grass crop, Orth et al. (2012) observed results that reinforce the dry mass productivity found in the present 
study in the first cut period, being this of $5600 \mathrm{~kg} \mathrm{ha}^{-1}$ with a minimum amplitude of variation between the studies, constituting only $5.4 \%$ when compared with the treatment with the irrigation depth with $140 \%$ of ETo-EP, or $2.01 \%$ when compared to the treatment with the irrigation depth with $100 \%$ of ETo-EP. According to Jaleel et al. (2009), leaf expansion is directly affected by water stress, due to inhibition of cell growth, as physiological processes such as photosynthesis and respiration are strongly influenced by water deficit, leading to a lower LAl and consequently a decrease in DM.

For Ferraz et al. (2012), the adequate water supply provides an increase in gas exchange between plant and atmosphere, resulting in plant tissue expansion and LAI development. Müller \& Bergamaschi
(2005), explains that the increase in production of dry mass and LAl when irrigated, is due to the significant increase in $\mathrm{CO}_{2}$ assimilation by the surface and photosynthetic active radiation, causing an increase in transpiration and consequently in water consumption.

Oliveira et al. (2007), while working with biomass production and leaf area index, observed a linear increase of dry mass according to the increase of leaf area.

At 50 DAS, the highest averages of DM production were observed for all treatments tested, in relation to the other standardization cuts, but the LAI presented highest averages in the second cut (80 DAS), as shown in Figure $3 \mathrm{~A}$ and Figure $3 \mathrm{~B}$, revealing that the proportion between leaves and stems changed after the first cut.

A

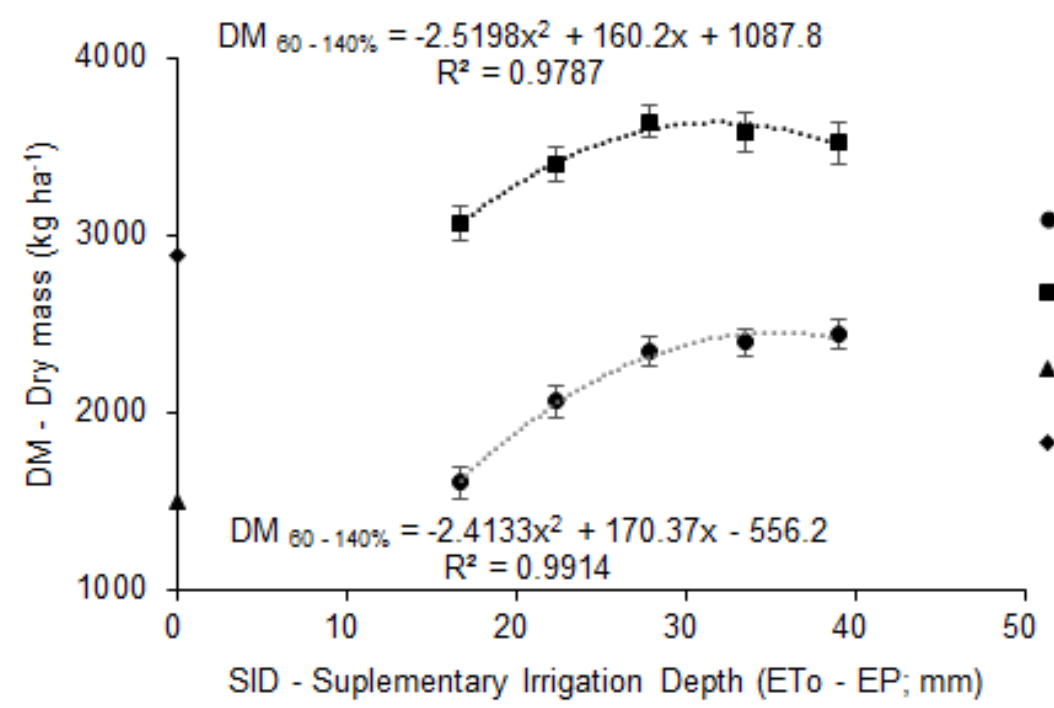

- (65 DAS) DM [60\% to $140 \%$ (ETo - EP)]

- (80 DAS) DM [60\% to $140 \%$ (ETo - EP)]

- (65 DAS) DM [0\% (ETo - EP)]

- (80 DAS) DM [0\% (ETo - EP)]

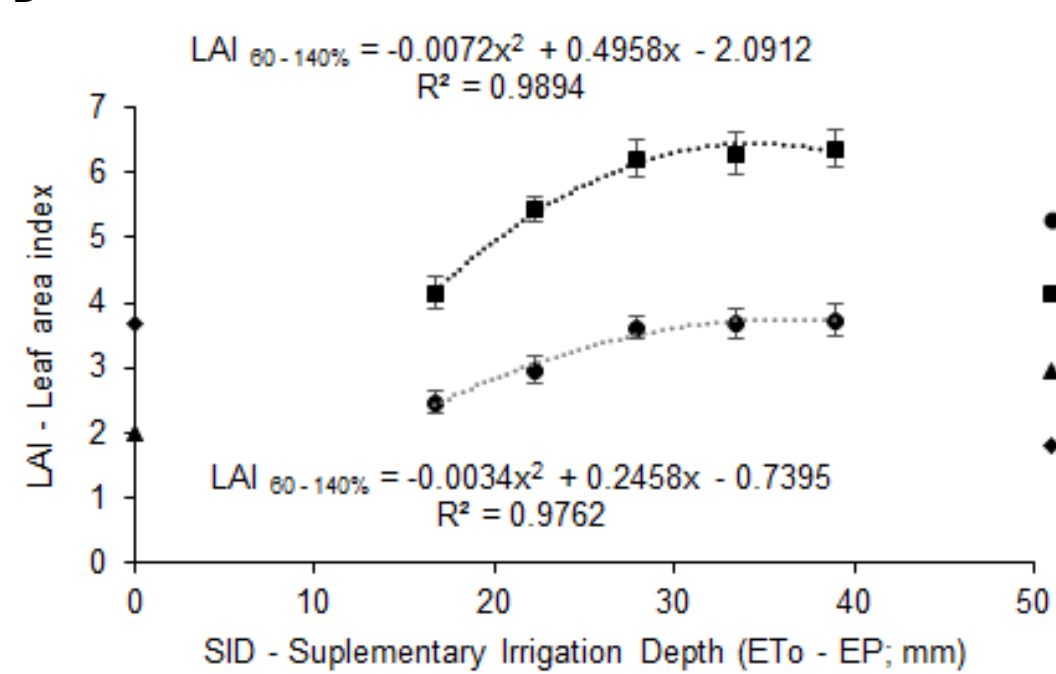

- (65 DAS) LAl [60\% to $140 \%$ (ETo - EP)]

- (80 DAS) LAl [60\% to $140 \%(E T o-E P)]$

^ (65 DAS) LAI [0\% (ETo - EP)]

- (80 DAS) LAl [0\% (ETo - EP)]

Figure 3 - Dry mass $(A)$ and leaf area index $(B)$ at 65 and 80 days after sowing (DAS) under irrigation depths $0 \%$, $60 \%, 80 \%, 100 \%, 120 \%$ and $140 \%$ of ETo-EP, with standards errors for each dot represented.

At 65 DAS, it was observed that the treatment without irrigation showed the lowest averages for both LAI and DM production, demonstrating that the water supply was insufficient for the satisfactory development of the crop. The DM production observed in the period ranged from $1493.75 \mathrm{~kg} \mathrm{ha}^{-1}$ in the treatment without 
irrigation to $2439.13 \mathrm{~kg} \mathrm{ha}^{-1}$ in the treatment with the irrigation depth at $140 \%$ of ETo-EP, presented a range of variation of $945.4 \mathrm{~kg} \mathrm{ha}^{-1}$, representing an increase in DM production of $39.8 \%$, only 15 days after the first cut.

In the treatment without irrigation the average observed for the LAl was 1.99, while in the treatment with the irrigation depth at $140 \%$ of ETo-EP the observed value was 3.73 , presenting variation amplitude of 1.74 between the higher and lower average, representing an increase of $47.7 \%$ in the LAI.

At the time of the second cut, the same behavior as the previous seasons was observed, presenting in a quadratic way for both DM and LAI. Where the lowest averages observed were in the treatment without irrigation, followed by treatment with the irrigation depth with $60 \%$ of ETo-EP, the highest averages occurred in the treatment with irrigation depth at $140 \%$ of ETo-EP for both variables, however, it is possible to observe that the treatments with $100 \%, 120 \%$ and $140 \%$ of ETo-EP did not differ statistically between themselves, presenting stable production.

The DM production was $2877.08 \mathrm{~kg} \mathrm{ha}^{-1}$ in the treatment without irrigation, while the treatment whith $100 \%$ of ETo-EP, showed an increase in the production of $761.9 \mathrm{~kg} \mathrm{ha}^{-1}$, being produced $3519.3 \mathrm{~kg} \mathrm{ha}^{-1}$ of DM. The treatment with the irrigation depth at $140 \%$ of ETo-EP presented the highest average of the whole experimental period, with $\mathrm{LAl}$ at 6.36 , while the treatment without irrigation presented 3.67 , showing a range of variation between the higher and the lowest average of 2.69, being the largest variation observed among all periods of evaluation, which corresponds to an increase of $42.3 \%$ in the LAl.

However, it was observed that the production in treatments with irrigation depths with $100 \%, 120 \%$ and $140 \%$ ETo-EP were very close, not showing statistical significance, with a variation of only $120.3 \mathrm{~kg} \mathrm{ha}^{-1} \mathrm{DM}$, demonstrating a tendency to stabilize production.

Considering the results obtained, it is possible to observe that at the time of the first cut (50 DAS), the DM yield presented the highest averages; however, the LAI showed lower values than in the second cut (80 DAS), that was because the period between sowing and the first cut the crop has a lower tillering rate, and thus a lower LAl, but with higher height and stem diameter lead to higher dry mass production, but with a predominance of stalks in the leaf / stem ratio, as can be observed in Table 5.

Table 5 - Leaf/stem ratio ${ }^{(*)}$ in different evaluation periods under irrigation depths $(0 \%, 60 \%, 80 \%, 100 \%, 120 \%$ and $140 \%$ of ETo-EP).

\begin{tabular}{cccccccc}
\hline $\begin{array}{c}\text { Irrigation dephts } \\
\text { (\% of ETo-EP) }\end{array}$ & 50 & 65 & 80 & 94 & 110 & 124 & 140 \\
\cline { 2 - 7 } & $0.58 \mathrm{~ns}$ & $0.83 \mathrm{c}$ & $1.05 \mathrm{~ns}$ & $0.57 \mathrm{~d}$ & $0.89 \mathrm{~ns}$ & $1.16 \mathrm{~ns}$ & $0.93 \mathrm{c}$ \\
60 & $0.64 \mathrm{~ns}$ & $0.92 \mathrm{a} \mathrm{b}$ & $1.12 \mathrm{~ns}$ & $0.60 \mathrm{~d}$ & $0.92 \mathrm{~ns}$ & $1.22 \mathrm{~ns}$ & $0.94 \mathrm{c}$ \\
80 & $0.65 \mathrm{~ns}$ & $0.90 \mathrm{a} \mathrm{b}$ & $1.08 \mathrm{~ns}$ & $0.73 \mathrm{c}$ & $0.96 \mathrm{~ns}$ & $1.21 \mathrm{~ns}$ & $0.97 \mathrm{~b} \mathrm{c}$ \\
100 & $0.67 \mathrm{~ns}$ & $1.28 \mathrm{a}$ & $1.19 \mathrm{~ns}$ & $0.83 \mathrm{~b}$ & $0.95 \mathrm{~ns}$ & $1.22 \mathrm{~ns}$ & $1.05 \mathrm{a}$ \\
120 & $0.65 \mathrm{~ns}$ & $0.84 \mathrm{c}$ & $1.06 \mathrm{~ns}$ & $0.88 \mathrm{ab}$ & $0.98 \mathrm{~ns}$ & $1.12 \mathrm{~ns}$ & $1.02 \mathrm{ab}$ \\
140 & $0.63 \mathrm{~ns}$ & $0.84 \mathrm{c}$ & $1.07 \mathrm{~ns}$ & $0.92 \mathrm{a}$ & $1.02 \mathrm{~ns}$ & $1.08 \mathrm{~ns}$ & $0.99 \mathrm{abc}$ \\
\hline
\end{tabular}

${ }^{(*)}$ means followed by different letters in the column differ by Tukey's test at $5 \%$ probability of error; ns - not significant.

In the second cut, the highest LAI was observed among all the evaluation periods, thus increasing the nutritional quality of the forage, due to the greater digestibility and availability of nutrients present in the leaves, being considered the best moment for animal feeding. After the cut, physiological stimulation to the tillering occurs, generating a larger number of plants and consequently higher LAl, but with smaller diameter and height of stalks (Kirchner et al., 2017).

Zwirtes et al. (2015) corroborates the results observed in the present study, where sorghum plants morphological characteristics and yield submitted to deficient irrigation were observed, finding the highest LAls in the second cut.

Ferrari et al. (2015) state that the occurrence of water deficiency causes changes in plant functioning, such as reduction of leaf water potential, stomatal closure, reduction of photosynthetic rate, reduction of aerial part, acceleration of senescence, foliar abscission, among others. Ferraz et al. (2012) define that by increasing the availability of water, plants increase the exchange of gases between plant and atmosphere, causing the expansion of plant tissue and the development of the aerial part, mainly leaves.

The results observed in the period of the third cut are represented in Figure 4A and Figure 4B. It can be observed that there was a decrease in the production of DM and LAI in relation to the second cut, due to the natural decrease of the crop yield potential, as well as of the conditions such as the reduction of photoperiod, temperature and solar radiation; however, the behavior of the culture in relation to the irrigation depths tested presented the same behavior as previous evaluations. 
A

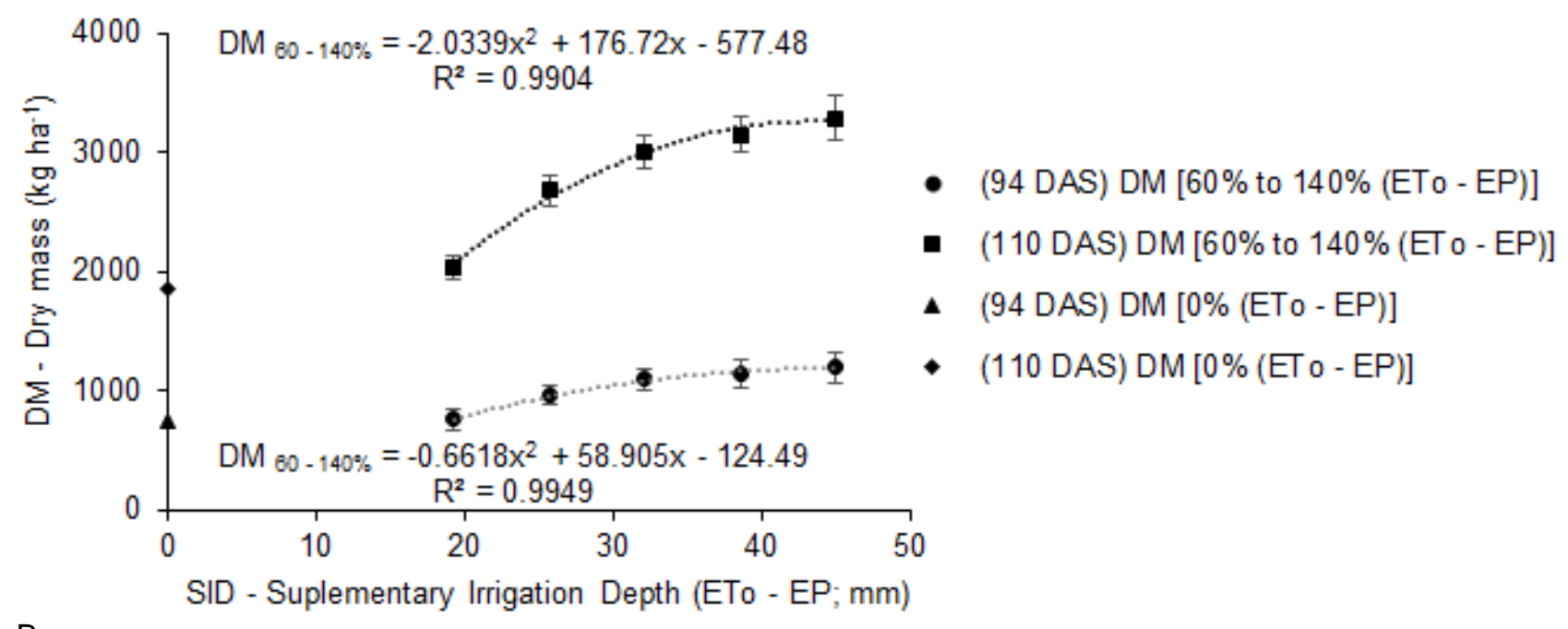

B

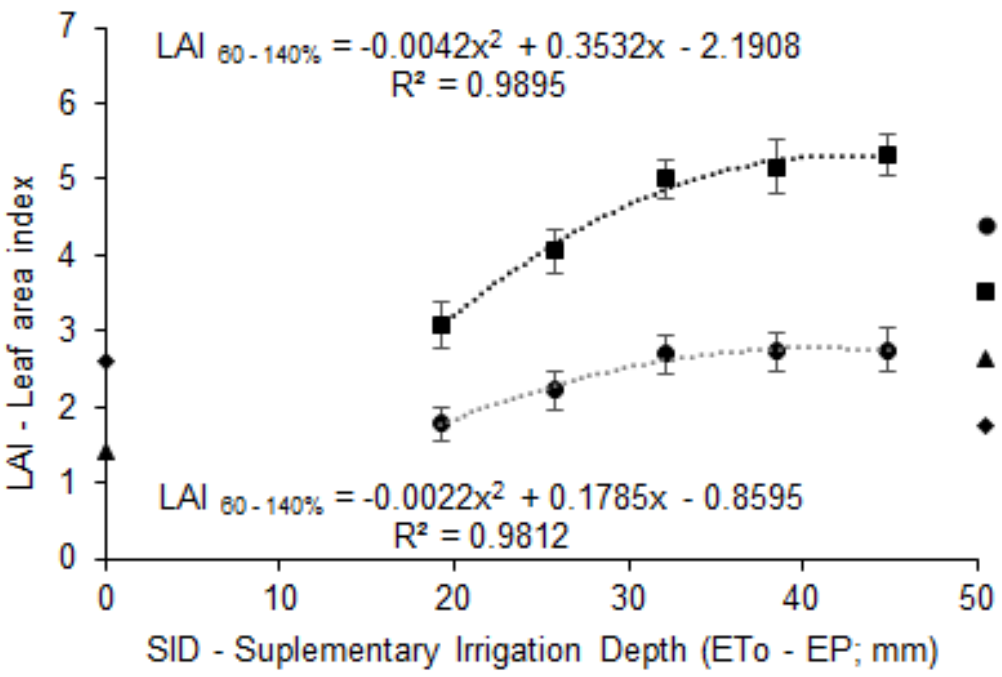

- (94 DAS) LAl [60\% to $140 \%$ (ETo - EP)]

- (110 DAS) LAI [60\% to $140 \%$ (ETo - EP)]

- (94 DAS) LAI [0\% (ETo - EP)]

- (110 DAS) LAl [0\% (ETo - EP)]

Figure 4 - Dry mass (A) and leaf area index (B) at 94 and 110 days after sowing (DAS) under irrigation depths 0 , $60 \%, 80 \%, 100 \%, 120 \%$ and $140 \%$ of ETo-EP, with standards errors for each dot represented.

At 94 DAS, the lowest mean values for both DM and LAl were in the treatment without irrigation. In the treatment with the irrigation depth with $140 \%$ of ETo-EP, the highest averages were observed, where the amplitude of variation between the highest and the lowest average for the DM production was $494.5 \mathrm{~kg} \mathrm{ha}^{-1}$ corresponding to an increase in the production of $39.1 \%$, and for the LAl of 1.33 corresponding to an increase of $49.4 \%$.

The DM production in the treatment without irrigation was $739.71 \mathrm{~kg} \mathrm{ha}^{-1}$, while in the treatment with the irrigation depth with $140 \%$ of ETo-EP the production was $1194.69 \mathrm{~kg} \mathrm{ha}^{-1}$, however, it must It should be noted that the production in treatments with irrigation depths with $80 \%, 100 \%, 120 \%$ and $140 \%$ of ETo-EP were close and did not show statistical significance between these treatments.

At the time of the third cut, the lowest averages for both variables were observed in the treatment without irrigation, and the highest in the treatment with irrigation depth at $140 \%$ of ETo-EP. The yield of DM in the treatment without irrigation was $1853.3 \mathrm{~kg} \mathrm{ha}^{-1}$, and the treatment with irrigation depth at $140 \%$ of ETo-EP showed a production of $3288.8 \mathrm{~kg} \mathrm{ha}^{-1}$, generating an increase in the production of $43.7 \%$ due to the use of irrigation.

But it is important to note that the variation between treatments with $100 \%, 120 \%$ and $140 \%$ of ETo-EP was only $8.7 \%$, with no statistical significance between them, following the same behavior of the previous evaluation, demonstrating that from the irrigation depth with $100 \%$ ETo-EP, production tends to stabilize.

The LAI in the treatment without irrigation was 2.61 , while in the treatment with the depth of irrigation at $140 \%$ of ETo-EP it was 5.31 , presenting an increase in the LAI of $51.9 \%$ when irrigated, however, treatments with $100 \%, 120 \%$ and $140 \%$ of ETo-EP followed the same trend as DM production, presenting LAI stabilization and not showing statistical significance between these treatments. 
Ghelfi Filho (1972 and 1978) working with Elephant-grass (Pennisetum purpureum Schum) and Guinea-grass (Panicum maximum Jacq.) showed results in line with those observed in the present study, in which he found that irrigation provided an average of $44 \%$ increase in forage production in summer period.

Magalhães et al. (2013), contribute by stating that tillers naturally are more sensitive to water deficit than the mother plant, which causes the death of tillers and, consequently, falls in forage production directly influenced by the decrease of leaf area index.

Nabinger (1997) reports that the first strategy of the plant to adapt to the conditions of water stress is the reduction of the aerial part in favor of the roots, limiting its capacity to compete for light, presenting a decrease in forage production proportional to the decrease in the LAI.

In the fourth and last cut of the crop, the averages observed were the lowest of the whole experimental period, as shown in Figure 5A and Figure 5B.

A

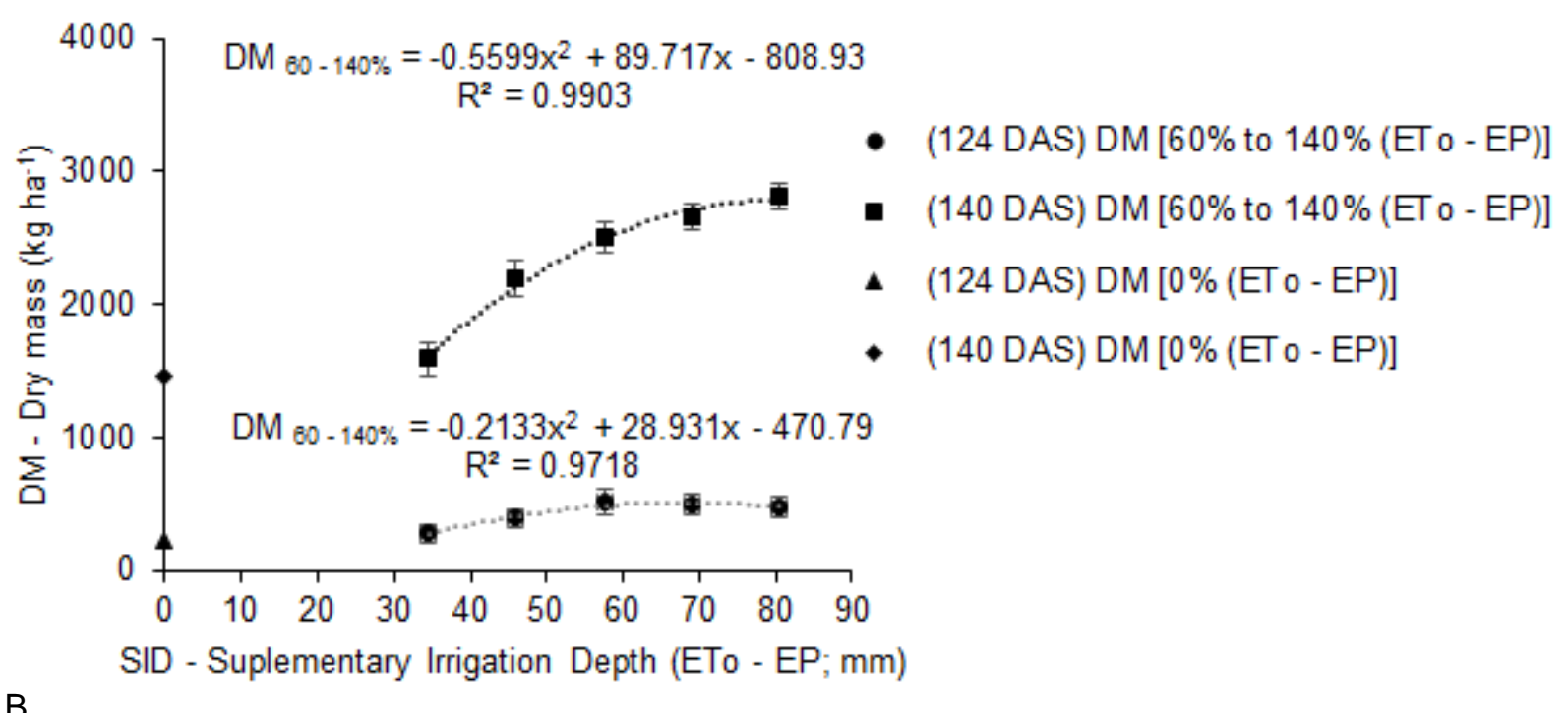

B

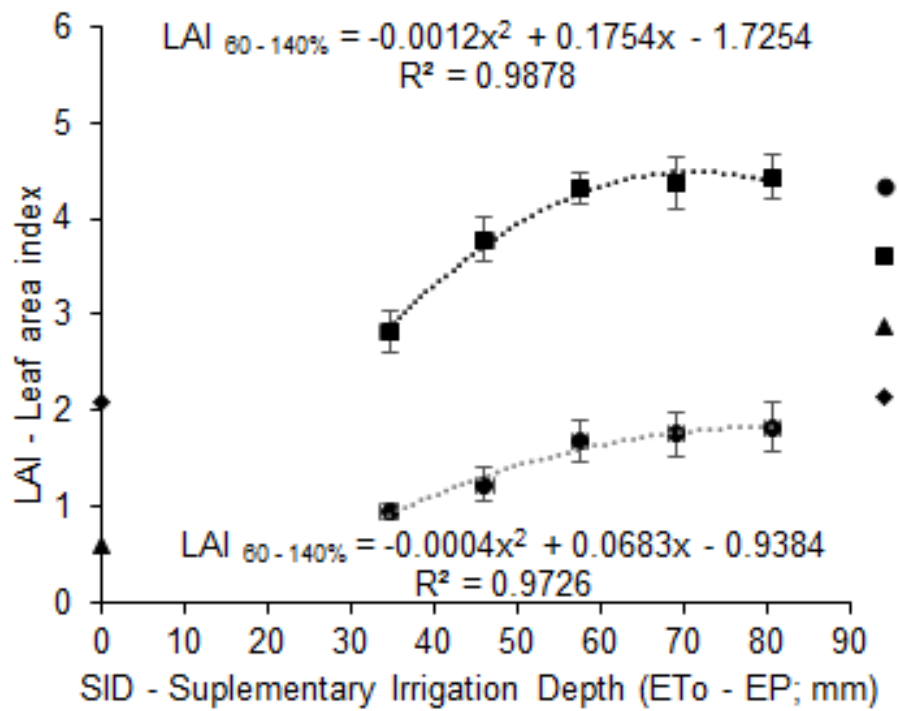

- (124 DAS) LAl [60\% to $140 \%$ (Eto - EP)]

- (140 DAS) LAI [60\% to $140 \%$ (ETo - EP)]

- (124 DAS) LAI [0\% (ETo - EP)]

- (140 DAS) LAl [0\% (ETo - EP)]

Figure 5 - Dry mass (A) and leaf area index (B) at 124 and 140 days after sowing (DAS), under irrigation depths $0 \%, 60 \%, 80 \%, 100 \%, 120 \%$ and $140 \%$ of ETo-EP, with standards errors for each dot represented.

It is observed that the fourth cut presented the lowest averages; such fact can be attributed to the period of regrowth and development of the crop, after the third cut is carried out around the time when temperatures and solar radiation decrease in the state of Rio Grande do Sul.

It is also attributed the reduction of production to the fact that the crop is at a low productive stage due to cuts previously made, where the combination of these factors, significantly affected the production of DM and LAl.

The temperature is a limiting factor for the Sudan grass crop, presenting a decrease in yields when solar radiation and temperature decrease, presenting minimal development when the soil temperature is below $20 \stackrel{\circ}{\circ} \mathrm{C}$ (Gontijo et al., 2008). 
At 124 days after sowing (DAS), it was observed that the lowest averages for both dry mass (DM) and leaf area index (LAI) were obtained in the treatment without irrigation, with values of 0.6 for $\mathrm{LAl}$ and DM $222.08 \mathrm{~kg} \mathrm{ha}^{-1}$.

The highest averages observed were in different treatments, with LAl in the treatment with the irrigation $d$ at $140 \%$ of ETo-EP, with 1.83, presenting a strong increase in relation to non-irrigated treatment, being $67.3 \%$, and the production of DM in the treatment with the irrigation depth at $100 \%$ of ETo-EP, with $510.83 \mathrm{~kg} \mathrm{ha}^{-1}$ corresponding to an increase in production of $53.7 \%$.

At the time of the fourth and last cut, although it presented the lowest averages of the whole experimental period, it is important to emphasize the relationship between LAI and DM production, which presented very similar behavior, even in the period when climatic and plant physiological conditions were unfavorable.

The lowest averages were in the treatment without irrigation for both variables, presenting values of 2.1 for LAl and $1452.5 \mathrm{~kg} \mathrm{ha}^{-1}$ for the production of DM. The highest averages were obtained in the treatment with irrigation depth at $140 \%$ of ETo-EP, presenting 4.43 for the $\mathrm{LAl}$, representing an increase of $52.6 \%$, and $2815.15 \mathrm{~kg} \mathrm{ha}^{-1}$ for the production of DM, generating an increase of $49.4 \%$ when supplementary irrigated, being able to provide quality feed to the animals even after having undergone three standardization cuts.

It is observed that the increase of the LAI and the production of DM as a function of the treatments tested are directly correlated, presenting proportional gains in both variables in all the evaluation periods.

The total production in the sum of the four standardization cuts was $9932.85 \mathrm{~kg} \mathrm{ha}^{-1}$ in the nonirrigated treatment, being obtained in the treatment with $140 \%$ of ETo-EP the production of $15541.55 \mathrm{~kg} \mathrm{ha}^{-1}$ which represents an increment of production of $46.1 \%$ as a function of the supplemental irrigation depth applied.

Vale \& Azevedo (2013), evaluating the productivity and quality of elephant grass and forage sorghum, irrigated with water from the groundwater and desalted tailings, obtained a productivity of $14500 \mathrm{~kg} \mathrm{ha}^{-1}$ of dry mass in the treatment irrigated with groundwater, being this value very close to the $14856.35 \mathrm{~kg} \mathrm{ha}^{-1}$ of dry mass found in the present study in the treatment with the irrigation depth with $100 \%$ of ETo.

Zwirtes (2013), evaluating the morphophysiological characteristics and productivity of forage sorghum submitted to deficient irrigation, also found results that are in line with those observed in the present study, being the greater dry mass yield in the treatment with the irrigation depth with $100 \%$ of ETc with $13785 \mathrm{~kg} \mathrm{ha}^{-1}$, under a four-cut regime, approaching the results observed in this experiment.

However, the treatments with the irrigation depth with $100 \%$ and $120 \%$ of ETo-EP presented a production of 14856.35 and $15198.95 \mathrm{~kg} \mathrm{ha}^{-1}$ respectively, being the amplitude of variation between the treatments with $100 \%, 120 \%$ and $140 \%$ of ETo-EP of only $4.4 \%$, not showing statistical significance and demonstrating the tendency of production stabilization with irrigation depths greater than $100 \%$ of ETo-EP.

In this way, farmers working with irrigated Sudan grass, must take into account their specific conditions, analyzing the fixed and variable costs, related and not related to irrigation, in order to obtain the irrigation depth that presents the highest economic return, since the evaluations in all the standardization of cuts presented the same production behavior.

In this way, the irrigation deficit must be used to the point where maximum economic efficiency is achieved, maximizing profits by reducing irrigation costs, it is always intended that the increase of production exceeds the financial investments for such (Vilas Boas et al. al., 2011).

An optimal irrigation under the economic focus implies the application of smaller depths in relation to full irrigation, even if there is some consequent reduction of productivity, but with some significant economic advantage. In irrigated crops, there may be situations in which the higher physical productivity does not coincide with higher profitability, since irrigation generates costs and increases in yield per area may not economically compensate the application of larger irrigation depths (Castro Junior et al., 2015).

In addition to the productive aspects, it is essential to know of water use efficiency (WUE) in irrigated agriculture, because it is possible to determine which treatment provides the greatest use of water by the plant, and it is possible to determine the economic viability of the activity.

In the sum of the applied water volume and the total dry mass production in the four standardization of cuts, the water use efficiency showed results that prove the importance of irrigation in the cultivation of pastures, as increase in irrigation depths to a certain extent provided greater conversion of dry mass per millimeter of applied water, as shown in Figure 6.

To determine the water use efficiency (WUE), the dry mass yields were added over the entire crop cycle, being related to the total volume of water applied (irrigation + effective precipitation). It presented quadratic behavior, with an acceptable coefficient of determination, demonstrating that the adequate water supply provides greater conversion of water into dry mass.

This fact is explained by Taiz \& Ziger (2017), who affirms that cultures in which aerial parts in the vegetative stage are harvested, fertilization and irrigation cause greater allocation of resources for stem, leaves and reproductive structures than for roots, and this deviation from the allocation pattern often results in higher productivity.

The control treatment showed water use efficiency of $16.06 \mathrm{~kg} \mathrm{~mm}^{-1}$, this being higher than the treatment with the supplementary irrigation depth with $60 \%$ of ETo-EP which presented the value of $15.07 \mathrm{~kg} \mathrm{~mm}^{-1}$, due to the water supplementation via irrigation being insufficient for the crop to express its 
productive potential and obtain an increase in dry mass proportional to the water supply. However, the highest WUE was observed in the treatment with the irrigation depth with 100\% ETo-EP with $18.62 \mathrm{~kg} \mathrm{~mm}^{-1}$, representing a variation in relation to the treatment without irrigation of $13.74 \%$, due to the total supply of the crop water needs, allowing it to express its productive potential and convert a greater volume of dry mass per millimeter of water applied, indicating that irrigation in Sudan grass must fully supply water demand in order to obtain the highest water use efficiency, as well as the highest forage yield.

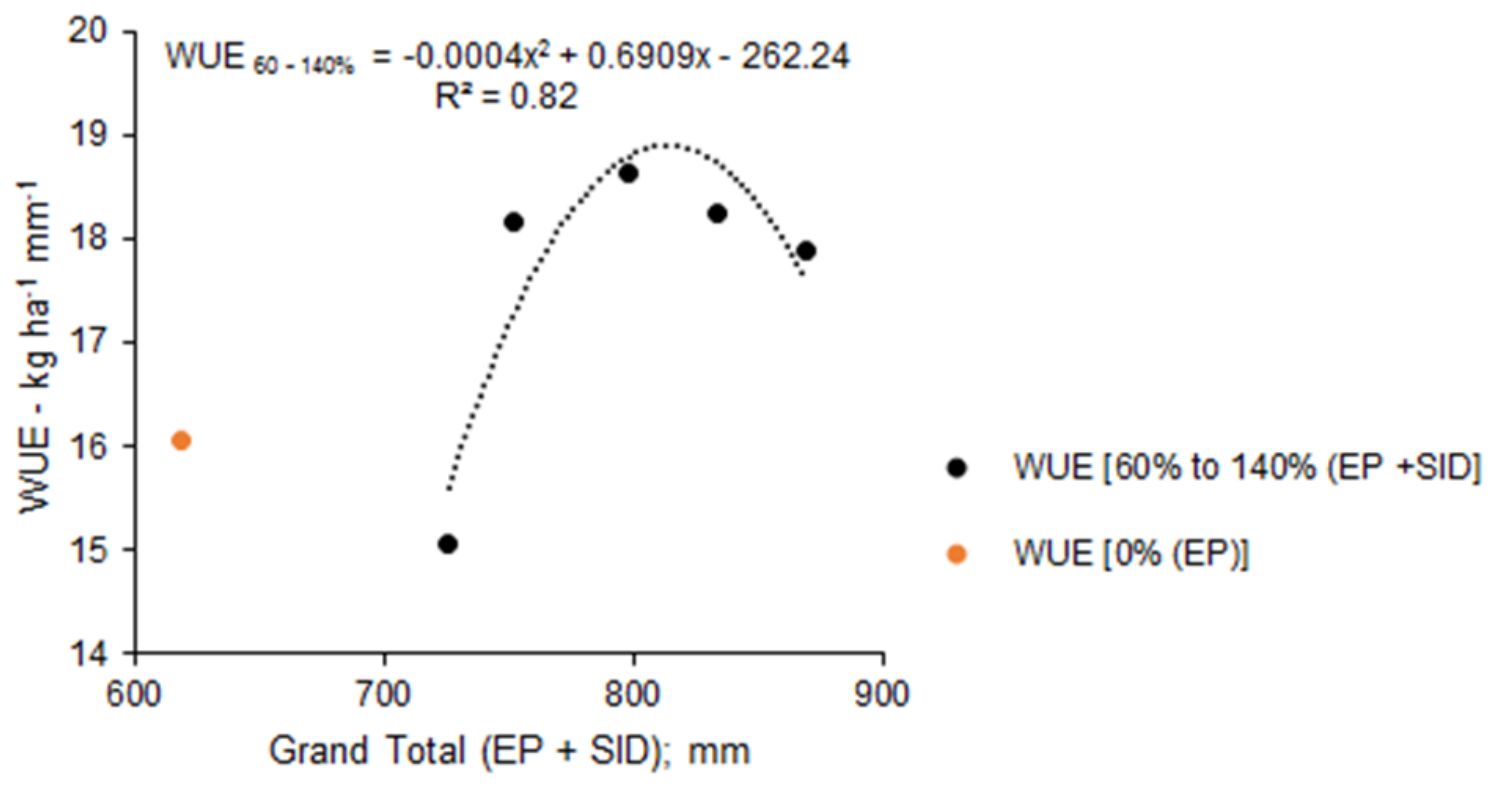

Figure 6 - Water use efficiency (WUE) in relation to total dry mass productivity and total sum of applied water, between effective precipitation and the supplementary irrigation treatments tested.

Treatments with irrigation depths greater than $100 \%$ of ETo-EP decreased the water use efficiency due to excess water caused by irrigation, the treatment with $140 \%$ of ETo-EP showed the value of $17.87 \mathrm{~kg} \mathrm{~mm}^{-1}$, this being lower than the treatment with $80 \%$ of ETo-EP which presented value of $18.16 \mathrm{~kg} \mathrm{~mm}^{-1}$, it is evident that excess irrigation negatively affects the water use efficiency by the crop and also increases costs.

Trentin et al. (2016), also working with the Sudan grass, cultivar BRS Estribo, obtained results close to those observed in the present study, where the water use efficiency was $18 \mathrm{~kg}$ of $\mathrm{DM} \mathrm{mm} \mathrm{m}^{-1}$ for the treatment with the irrigation depth with $50 \%$ of ETp, dry mass productivity of $11,032 \mathrm{~kg} \mathrm{ha}^{-1}$, with a water supply over the crop cycle of $613.1 \mathrm{~mm}$.

The observed results are in agreement with those obtained by Parizi et al. (2009), that working with the corn crop with four different water depths $60 \%, 80 \%$, $100 \%$ and $120 \%$ of ETo, found the highest WUE values of $3.41 \mathrm{~kg} \mathrm{~m}^{-3} \mathrm{ha}^{-1}$ and $3.46 \mathrm{~kg} \mathrm{~m}^{-3} \mathrm{ha}^{-1}$ in treatments with $80 \%$ and $100 \%$ ETo, presenting quadratic behavior, that is, depths greater than $100 \%$ decreased in the WUE

Studying the water use efficiency in the irrigated forage sorghum crop, Kirchner et al. (2019) also observed results that reinforce those found in the present study, since the adjusted equation was second degree, with the largest WUE in the treatment with $100 \%$ ETo and the lowest in the control treatment, with a range of variation between the different depths of water of $24.23 \%$, presenting 15.01 to $19.81 \mathrm{~kg} \mathrm{~mm}^{-1}$.

\section{Conclusions}

In treatments with supplementary irrigation depths with $100 \%, 120 \%$ and $140 \%$ ETo-EP, the values were close, showing a trend of stabilization of production in all periods of evaluation both for the leaf area index, as for dry mass production.

The lowest dry mass production was in the control treatment (without irrigation), as well as the leaf area index and the highest dry mass production and leaf area index were observed in treatments with supplementary irrigation depths with $100 \%, 120 \%$ and $140 \%$ of ETo-EP, indicating that the water demand for Sudan grass must be fully met in order to obtain high productivity and leaf area index.

The water use efficiency showed the highest value in the treatment with the irrigation depth with $100 \%$ of ETo-EP, presenting a decrease in the supplementary depths higher than that, indicating that the optimal water supply of the crop favors the maximum conversion of water to dry mass. The lowest value observed was in the treatment with the irrigation depth with $60 \%$ of ETo-EP, staying below the value observed in the control treatment, demonstrating that supplementary irrigation depths with a low percentage of water replacement should be avoided as they harm the WUE. 


\section{References}

Allen RG, Pereira LS, Raes D, Smith J (2006) Evapotranspiration del cultivo: guias para $\mathrm{La}$ determinación de los requerimientos de agua de los cultivos. Roma: FAO. (Estudio Riego y Drenaje, 56), 298p.

Bartero LM, Prado TF, Basso KL, Lima LA, Motta KM, Kruger BC, Neto LRM, Silva GAS (2013) Análise de crescimento em plantas forrageiras aplicada ao manejo de pastagens. Veterinária Notícias 19(2):71-85.

Bibi A, Sadaqat A, Akram HM, Khan TM, Usman BF (2010) Physiological and agronomic responses of sudangrass to water stress. Journal of Agricultural Research, 48 (1):369-379.

Castro Junior WL, Oliveira RA, Silveira SFR, Andrade Júnior AS (2015) Viabilidade econômica de tecnologias de manejo da irrigação na produção do feijão-caupi, na região dos Cocais- MA. Engenharia Agrícola 35(3):406-418 .

CQFS Comissão de Química e Fertilidade do Solo RS/SC (2016) Manual de adubação e calagem para os Estados do Rio Grande do Sul e de Santa Catarina. 11. ed. Porto Alegre: SBCS Núcleo Regional Sul/UFRGS.

Embrapa - Empresa Brasileira de Pesquisa Agropecuária (1997) Manual de métodos de análises de solo. 2. ed. Rio de Janeiro, Ministério da Agricultura e do Abastecimento. 212 p.

Embrapa - Empresa Brasileira de Pesquisa Agropecuária (2014) Revista Do Produtor. Bagé 6:18-19.

Ferrari E, Paz A, Silva AC (2015) Déficit hídrico no metabolismo da soja em semeaduras antecipadas no Mato Grosso. Nativa 3(1):67-77.

Ferraz RDS, Melo AS, Suassuna JF, Brito MEB, Fernandes PD, Nunes Júnior ES (2012) Trocas gasosas e eficiência fotossintética em ecótipos de feijoeiro cultivados no semiárido. Revista Pesquisa Agropecuária Tropical 42(2):181-188.

Ferreira JJ, Carneiro JC, Rodrigues JA, Barros Neto G (2000) Produção e composição bromatológica do capim Sudão e de seus híbridos (BRS 800 e AG 2501 C) com 42 e 56 dias. Reunião anual da Sociedade Brasileira de Zootecnia, 37, Viçosa: SBZ CD-ROM.

Ghelfi Filho, H. (1972) Efeito da irrigação sobre a produtividade do capim elefante (Pennisetum purpureum Schum.) variedade napier. USP-ESALQ Tese (Doutorado em Agronomia). 77p.

Ghelfi Filho, H. (1978) Efeito da irrigação sobre o capim colonião (Panicum maximum Jacq.). O Solo 68(1),12-15.

Gomes ACS, Robaina AD, Peiter MX, Soares FC, Parizi ARC (2014) Modelo para estimativa da produtividade para a cultura da soja. Ciência Rural 44(1):43-49.
Gomes EP, Rickli ME, Cecato U, Vieira CV (2015) Produtividade de capim Tifton 85 sob irrigação e doses de nitrogênio. Revista Brasileira de Engenharia Agrícola e Ambiental 19(4):317-323.

Gontijo MHR, Borges ALC, Gonçalves LC (2008) Potencial forrageiro de seis híbridos de sorgo com capim sudão. Revista Brasileira de Milho e Sorgo 7(1):33-43.

Gubiani PI, Reinert DJ, Reichert JM (2006) Método alternativo para a determinação da densidade de partícula do solo - exatidão, precisão e tempo de processamento. Ciência Rural 36: 664-668.

Jaleel CA, Manivannan P, Wahid A, Faroog M, Al-juburi HJ, Somasundaram R, Panneerselvam R (2009) Drought stress in plants: A review on morphological characteristics and pigments composition. International Journal of Agriculture and Biology 11:100-105.

Kirchner JH, Robaina AD, Peiter MX, Mezzomo W, Torres RR, Girardi LB, Pimenta BD, Rosso RB, Pereira AC, Loregian MV (2017) Variation of leaf area index of the forage sorghum under different irrigation depths in dynamic of cuts. African Journal of Agricultural Research 12(2):111-124.

Kirchner JH, Robaina AD, Peiter MX, Torres RR, Mezzomo W, Ben LHB, Pimenta BD, Pereira AC (2019) Funções de produção e eficiência no uso da água em sorgo forrageiro irrigado. Revista Brasileira de Ciências Agrárias 14(2):1-9 (e5646).

Lopes AS, Oliveira GQ, Filho SNS, Goes RJ, Camacho MA (2011) Manejo de irrigação e nitrogênio em feijoeiro comum cultivado em sistema de plantio direto. Revista Ciência Agronômica 42(1):51-56.

Magalhães JA, Carneiro MDS, Andrade AC, Pereira ES, Andrade AP, Bakke OA, Rodrigues BHN, Mochel Filho WJE, Costa NDL (2013) Características morfogênicas e estruturais do capim-andropogon sob irrigação e adubação. Semina: Ciências Agrárias, 34(5):2427-2436.

Mezzomo W, Peiter MX, Robaina AD, Kirchner JH, Torres RR, Pimenta BD (2020) Produção forrageira e eficiência de utilização da água do capim sudão submetido a diferentes lâminas de irrigação. Revista Irriga, 25(1)143-159.

Millar AA (1978) Drenagem de terras agrícolas: bases agronômicas. São Paulo: McGraw-Hill do Brasil, LTDA. $276 \mathrm{p}$

Monteiro ROC, Costa RNT, Leão MCS, Aguiar JV (2008) Eficiência do uso da água e nitrogênio na produção de melão. Revista Irriga 13(3):367-377.

Moreno JA (1961) Clima do Rio Grande do Sul. Porto Alegre, Secretaria da Agricultura. 64p. 
Müller AG, Bergamaschi H (2005) Eficiências de interceptação, absorção e uso da radiação fotossinteticamente ativa pelo milho (Zeamays $L$.), em diferentes disponibilidades hídricas e verificação do modelo energético de estimativa da massa seca acumulada. Revista Brasileira de Agrometeorologia 13(1):27-33.

Nabinger C (1997) Princípios da exploração intensiva de pastagens. In: Simpósio sobre manejo de pastagens, Piracicaba. Anais: Fundação de Estudos Agrários Luiz de Queiroz. p.15-95.

Oliveira RA, Daros E, Zambon JLC, Weber H, Ido OT, Filho JCB, Ribas KCZ, Silva DKT (2007) Área foliar em três cultivares de cana-de-açucar e sua correlação com a produção de biomassa. Pesquisa Agropecuária Tropical 37(2):71-76.

Oliveira VS, Morais JAS, Fagundes JL, Lima JCS, Santana JCS, Santos CB (2016) Efeito da irrigação na produção e qualidade de pastagens durante o período da seca. Revista Científica Eletrônica de Medicina Veterinária 26(0):1-10.

Orth R, Fontaneli RS, Fontaneli RS, Saccardo E (2012) Produção de forragem de gramíneas anuais semeadas no verão. Ciência Rural 42(9):1535-1540.

Parizi ARC, Robaina AD, Gomes ACS, Soares FC, Ramao C, Calegaro I, Peiter MX (2009) Efeito de diferentes estratégias de irrigação sobre a produção de grãos e seus componentes na cultura do milho. Irriga 14(s.n):254-269.

Schneider CA, Rasband WS, Eliceiri KW (2012) NIH Image to ImageJ: 25 years of image analysis. Nature methods 9(7):671-675.

Silveira MCTA, Sant'Anna DM, Montardo DP, Trentin G (2015) Aspectos Relativos à Implantação e Manejo de Capim-Sudão BRS Estribo. Embrapa - Comunicado Técnico 89, Bagé - RS ISSN 19825382.https://ainfo.cnptia.embrapa.br/digital/bitstream/it em/135361/1/COT89online.pdf (Acesso em 01 de Jul. 2019)
Streck EV, Kämpf $N$, Dalmolin RSD, Klamt E, Nascimento PC, Schneider P, Giasson E, Pinto LFS (2008) Solos do Rio Grande do Sul, 2. ed. Porto Alegre, EMATER/RS-ASCAR.

Taiz L, Zeiger E (2017) Fisiologia e desenvolvimento vegetal. 6 ed. Porto Alegre: Artmed, p. 888.

Torres RR, Robaina AD, Peiter MX, Ben LHB, Mezzomo W, Kirchner JH, Rosso RB, Pimenta BD, Pereira AC, Loregian MV (2019) Water productivity and production function in irrigated millet crop. Semina: Ciências Agrárias, 40(6)2:2837-2850.

Trentin G, Silveira MCT, Malcorra MP, Fagundes BF, Souza ALF (2016) Produção de matéria verde e seca de capim-Sudão BRS Estribo submetido a diferentes disponibilidades hídricas. In: Congresso Brasileiro de Zootecnia, 26, Santa Maria. Cinquenta anos de zootecnia no Brasil: anais. Santa Maria: Sociedade Brasileira de Zootecnia.

Vale MB, Azevedo PB (2013) Avaliação da produtividade e qualidade do capim elefante e do sorgo irrigados com água do lençol freático e do rejeito do dessalinizador. Revista Científica do Instituto Federal de Educação, Ciência e Tecnologia do Rio Grande do Norte 3(1):181-195.

Vilas Boas RC, Pereira GM, Reis RP, Lima Júnior JA, Consoni R (2011) Viabilidade econômica do uso do sistema de irrigação por gotejamento na cultura da cebola. Revista Ciência e Agrotecnologia 35(4):781788.

Zwirtes AL (2013) Características morfofisiológicas e produtividade de plantas de sorgo submetidas à irrigação deficitária. Universidade Federal de Santa Maria (UFSM) (Dissertação de Mestrado em engenharia agrícola).

Zwirtes AL, Carlesso R, Petry MT, Kunz J, Reimann GK (2015) Desempenho produtivo e retorno econômico da cultura do sorgo submetida à irrigação deficitária. Engenharia Agrícola 35(4):666-688. 